\title{
Tuberous Sclerosis 1
}

National Cancer Institute

\section{Source}

National Cancer Institute. Tuberous Sclerosis 1. NCI Thesaurus. Code C75122.

Tuberous sclerosis mapped to chromosome 9q34 (TSC1 gene). 